\title{
In vitro lipid metabolism, growth and metabolic hormone concentrations in hyperthyroid chickens*
}

\author{
By R. W. ROSEBROUGH AND J. P. MCMURTRY \\ Nonruminant Animal Nutrition Laboratory, Livestock and Poultry Science Institute, United States \\ Department of Agriculture-Agricultural Research Service, Beltsville Agricultural Research Center, \\ Beltsville, MD 20705, USA \\ AND R. VASILATOS-YOUNKEN \\ Department of Poultry Science, The Pennsylvania State University, University Park, \\ PA 16802, USA
}

(Received 20 February 1991 - Accepted 17 December 1991)

\begin{abstract}
Indian River male broiler chickens growing from 7 to $28 \mathrm{~d}$ of age were fed on diets containing energy : protein values varying from 43 to $106 \mathrm{MJ} / \mathrm{kg}$ protein and containing 0 or $1 \mathrm{mg}$ triiodothyronine $\left(T_{3}\right) / \mathrm{kg}$ diet to study effects on growth, metabolic hormone concentrations and in vitro lipogenesis. In vitro lipid synthesis was determined in liver explants in the presence and absence of ouabain $\left(\mathrm{Na}^{+}, \mathrm{K}^{+}\right.$ transporting ATPase (EC 3.6.1.37) inhibitor) to estimate the role of enzyme activity in explants synthesizing lipid. Growth and feed consumption increased $(P<0.01)$ when the energy: protein value decreased from 106 to $71 \mathrm{MJ} / \mathrm{kg}$ protein; however, both variables decreased as the value was further decreased from 53 to $43 \mathrm{MJ} / \mathrm{kg}$ protein. Triiodothyronine depressed $(P<0.01)$ growth, but not food intake. Large energy:protein diets $\left(>53 \mathrm{MJ} / \mathrm{kg}\right.$ protein) and dietary $T_{3}$ lowered $(P<0.01)$ plasma growth hormone. Large energy: protein diets $(>53 \mathrm{MJ} / \mathrm{kg}$ protein) increased $(P<0.01)$ lipogenesis, plasma growth hormone (GH) and decreased plasma insulin-like growth factor 1 (IGF-1). Also, $T_{3}$ decreased plasma GH, IGF-1 in vitro lipogenesis. Ouabain inhibited a greater proportion of in vitro lipogenesis in those explants synthesizing fat at a high rate. Both dietary $T_{3}$ and in vitro ouabain decrease lipogenesis, but, when combined, the effects are not cumulative.
\end{abstract}

Lipogenesis: Dietary protein: ATPase: Thyroid hormones: Chickens

The effect of dietary protein on weight gain and body composition of broiler chickens is well known. Diets containing large energy: protein values (greater than $13 \mathrm{MJ} / \mathrm{kg}$ diet and more than $72 \mathrm{MJ} / \mathrm{kg}$ crude protein (nitrogen $\times 6.25$ )) promote high rates of in vitro lipogenesis (Rosebrough \& Steele, 1985) as well as de novo carcass lipid synthesis by the liver (Donaldson, 1985). Diets with small energy: protein values (less than $13 \mathrm{MJ} / \mathrm{kg}$ diet and less than $56 \mathrm{MJ} / \mathrm{kg}$ crude protein) promote lean broiler carcasses (Donaldson et al. 1956; Thomas \& Combs, 1967). Those diets containing large energy: protein values may direct nutrients from lean to fat synthesis. It is also reasonable to assume that an increase in nutrient flux to support de novo lipid synthesis may require an increase in energydependent transport processes. Maintenance of the cellular $\mathrm{Na}^{+}-\mathrm{K}^{+}$gradient seems related to accelerated tissue metabolism. For example, Adeola et at. (1989) and Milligan \& McBride (1985) have reported that one of these processes, $\mathrm{Na}^{+}, \mathrm{K}^{+}$-transporting ATPase (EC 3.6.1.37)-dependent respiration, can account for $20-30 \%$ of the total oxygen consumption of porcine muscle synthesizing protein.

\footnotetext{
* Mention of a trade name, proprietary product or vendor does not constitute a guarantee or warranty of the product by USDA or imply its approval to the exclusion of other suitable products or vendors.
} 
Although lipogenesis is another highly anabolic process, there are no findings that we are aware of that suggest a direct role for $\mathrm{Na}^{+}, \mathrm{K}^{+}$-transporting ATPase-dependent processes accompanying lipogenesis resulting from the feeding of diets containing large energy: protein values. Certain studies using rodents have shown that obese mice had lower $\mathrm{Na}^{+}, \mathrm{K}^{+}$-transporting ATPase activity than their lean littermates (Berdanier \& Shubeck, 1981). Other work has shown that the number of ouabain-binding sites in liver could be taken as an estimate of $\mathrm{Na}^{+}, \mathrm{K}^{+}$-transporting ATPase units and that this estimate was lower in obese compared with lean littermates. Ismail-Beigi \& Edelman (1970) reported that thyroid hormones stimulated $\mathrm{O}_{2}$ consumption through an increase in $\mathrm{Na}^{+}, \mathrm{K}^{+}$-transporting ATPase. When thyroid hormones were given to either lean or obese rats, ouabain-binding sites were increased to a greater degree in the obese rat. Thus, it has been shown that a metabolic error resulting in severe obesity in rodents resides in that portion of mitochondrion involved in respiratory control (Berdanier \& Shubeck, 1981; Kim \& Berdanier, 1989). Furthermore, this error has also been related to thyroid hormones (York et al. 1978; Hillgartner \& Romsos, 1985).

The purpose of the present study was to examine the thyroid hormone $\times \mathrm{Na}^{+}, \mathrm{K}^{+}$transporting ATPase axis in broiler chickens subjected to dietary regimens designed to promote different rates of lipogenesis. The hypothesis tested was that the regulation of lipogenesis during the feeding of diets containing large energy: protein values is similar to genetic obesity, e.g. reduced $\mathrm{Na}^{+}, \mathrm{K}^{+}$-transporting ATPase activity. Of particular interest was the determination of the effect of the known $\mathrm{Na}^{+}, \mathrm{K}^{+}$-transporting ATPase inhibitor ouabain (Glynn, 1964) on lipogenesis in the chicken made hyperthyroid by dietary additions of triiodothyronine $\left(T_{3}\right)$. In addition, circulating $T_{3}$, thyroxine $\left(T_{4}\right)$, growth hormone $(\mathrm{GH})$ and insulin-like growth factor-1 (IGF-1) were monitored to determine the potency of dietary thyroid hormones as moderators of whole animal metabolism.

\section{MATERIALS AND METHODS}

\section{Animals}

Male, Indian River broiler chickens were grown under common conditions from 1 to $7 \mathrm{~d}$ of age. The chickens were housed in battery-brooders in an environmentally controlled room maintained at $23^{\circ}$ with a $12 \mathrm{~h}$ light - dark cycle $(06.00-18.00$ hours light). Treatments were randomly assigned to pens in each battery. Both feed and water were apportioned on an ad lib. basis. For purposes of statistical analyses, the observation was the pen mean.

\section{Experimental treatments}

At $7 \mathrm{~d}$ of age, chickens were randomly assigned to one of eight dietary treatments $(106,71$, $53,43 \mathrm{MJ} / \mathrm{kg}$ protein +0 or $1 \mathrm{mg} \mathrm{T}_{3} / \mathrm{kg}$ diet) for a $7-28 \mathrm{~d}$ growth trial. The eight dietary treatments formed a $4 \times 2$ factorial arrangement with a total of eight pen replicates (six birds per pen) for each dietary treatment. The different levels of dietary crude protein were obtained by mixing the two basal diets in Table 1 . In addition, a third treatment, 0 or 1 mm-ouabain, was superimposed on liver explants from all treatment groups to determine the effect of the two dietary treatments on in vitro intermediary metabolism.

\section{In vitro metabolism}

Optimizing conditions for in vitro metabolism have been described by Rosebrough $\&$ Steele (1987). Briefly, the methods are as follows: two 28-d-old chickens were randomly selected from each pen replicate treatment per treatment and killed by cervical dislocation at 09.00 hours. The livers were rapidly excised, weighed and placed in individual vessels containing 10 mM-HEPES ( $N$-2-hydroxyethyl piperazine- $N^{\prime}$-2-ethane sulphonic acid) and $155 \mathrm{~mm}$ - 
Table 1. Composition of the basal diets $(\mathrm{g} / \mathrm{kg}$ diet $)$

\begin{tabular}{|c|c|c|}
\hline Dietary energy:protein $(\mathrm{MJ} / \mathrm{kg}$ protein $) \ldots$ & 106 & 43 \\
\hline \multicolumn{3}{|l|}{ Ingredient } \\
\hline Isolated soya-bean protein* & - & 100 \\
\hline Soya-bean meal & 112 & 400 \\
\hline Maize meal & 767 & 400 \\
\hline Maize oil & 17 & 40 \\
\hline Sand & 15 & - \\
\hline Dicalcium phosphate & 40 & 40 \\
\hline Limestone & 10 & 10 \\
\hline L-methionine $\dagger$ & 5 & \\
\hline Selenium premix & 1 & 1 \\
\hline Mineral premix $\S$ & 1 & 1 \\
\hline Vitamin premix $\|$ & 5 & 5 \\
\hline Crude protein (nitrogen $\times 6.25)(\mathrm{g} / \mathrm{kg})$ & 120 & 300 \\
\hline Metabolizable energy $(\mathrm{MJ} / \mathrm{kg})$ & $12 \cdot 8$ & $12 \cdot 8$ \\
\hline Lysine $(\mathrm{g} / \mathrm{kg})$ & $6 \cdot 0$ & $17 \cdot 3$ \\
\hline Sulphur amino acids $(\mathrm{g} / \mathrm{kg})$ & $10 \cdot 3$ & $10 \cdot 3$ \\
\hline
\end{tabular}

* Soya-bean protein grade II (900 g crude protein/kg, 21726); Nutritional Biochemicals, PO Box 22400 , Cleveland, Ohio 44122, USA.

$\dagger$ L-methionine (18915), US Biochemicals, PO Box 22400, Cleveland, Ohio 44122, USA.

Provided $0.2 \mathrm{mg}$ selenium $/ \mathrm{kg}$ diet.

$\$$ Provided (mg/kg diet): manganese 100, iron 100, copper 10, cobalt 1 , iodine 1 , zinc 100 and calcium 89.

$\|$ Provided (mg/ $\mathrm{kg}$ diet) : retinol 3.6, cholecalciferol 0.075 , biotin 1, vitamin E 10, riboflavin 10, pantothenic acid 20 , choline $2 \mathrm{~g}$, niacin 100 , thiamine 10 , vitamin $\mathrm{B}_{6} 10$, menadione sodium bisulphite $1 \cdot 5$, cyanocobalamin $0 \cdot 1$, folic acid 2 and ethoxyquin 150 .

sodium chloride ( $\mathrm{pH} 7 \cdot 5)$. Pieces of fresh livers were sliced with a tissue chopper (Macllwain Tissue Chopper; Mickle Laboratory Engineering Company, Gomshall, Surrey, UK) at a setting corresponding to a thickness of $0.3 \mathrm{~mm}$ to give explants weighing from 35 to $75 \mathrm{mg}$. The explants were placed in $75 \mathrm{~mm}$ Petri dishes containing the chilled buffer and randomly allocated to in vitro treatments. Duplicate explants were incubated at $37^{\circ}$ for $2 \mathrm{~h}$ in Hanks' balanced salts (Hanks \& Wallace, 1949) supplemented with $10 \mathrm{mM}-$ HEPES and $20 \mathrm{~mm}$ sodium[2- $\left.{ }^{14} \mathrm{C}\right]$ acetate (New England Nuclear, Boston, Massachusetts 02118) (20 disintegrations/min per nmol) +0 or $1 \mathrm{~mm}$-ouabain. All incubations were conducted in a volume of $3 \mathrm{ml}$ at $37^{\circ}$ for $2 \mathrm{~h}$ under an $\mathrm{O}_{2}-\mathrm{CO}_{2}(95: 5, \mathrm{v} / \mathrm{v})$ atmosphere. Slices were removed from incubation flasks and extracted for $24 \mathrm{~h}$ in $15 \mathrm{ml}$ chloroform--methanol $(2: 1$, $\mathrm{v} / \mathrm{v})$ in $20 \mathrm{ml}$ glass scintillation vials. Slices were then discarded and $2 \mathrm{ml} 117 \mathrm{~mm}-$ potassium chloride added to the chloroform-methanol extract (Folch et al. 1957). After vigorous shaking, phase separation was allowed and the upper phase discarded. The lower phase was washed with $5 \mathrm{ml}$ methanol-117 $\mathrm{mm}-\mathrm{NaCl}(3: 2, \mathrm{v} / \mathrm{v})$, shaken and again allowed to separate. The upper phase was discarded and the lower phase evaporated to dryness, dispersed in $10 \mathrm{ml}$ scintillation cocktail, and counted by liquid-scintillation spectroscopy.

The remainder of each liver was homogenized in $100 \mathrm{~mm}$-HEPES, pH 7.5 (Research Organics Inc., Cleveland, Ohio 44125)-3.3 mm-mercaptoethanol $(1: 10, \mathrm{w} / \mathrm{v})$ and centrifuged (Beckman J2-21; Beckman Instruments, Inc., Palo Alto, CA 94304) at $50000 \mathrm{~g}$ for 60 min. The supernatant fractions were kept at $0^{\circ}$ until analysed for malic enzyme $(E C 1.1 .1 .40 ; \mathrm{ME})$, isocitrate dehydrogenase $\left(\mathrm{NADP}^{+}\right)(E C 1.1 .1 .42 ; \mathrm{ICD})$ and glutamic-oxaloacetic transaminase (EC 2.6.1.1; GOT).

ME activity was determined by a modification of the method of Hsu \& Lardy (1969). The reaction contained 50 mM-HEPES ( $\mathrm{pH} 7 \cdot 5$ ), 1 mM-NADP, 5 mM-manganese chloride and 
the substrate, $2 \cdot 2 \mathrm{~mm}$-L-malate (disodium salt). A $50 \mu \mathrm{l}$ portion of the $50000 \mathrm{~g}$ supernatant fraction was pre-incubated for $15 \mathrm{~min}$ in the presence of the first three ingredients. The reaction was initiated by adding L-malate and following the rate of reduction of NADP at $340 \mathrm{~nm}$ at $25^{\circ}$. The reaction proceeded linearly for at least 60 min providing that the reaction contained less than $100 \mu \mathrm{g}$ supernatant-fraction protein.

ICD activity was determined by a modification of the method of Cleland et al. (1969). The reaction contained $50 \mathrm{~mm}$-HEPES ( $\mathrm{pH} 7 \cdot 5$ ), $1 \mathrm{~mm}-\mathrm{NADP}, 5 \mathrm{~mm}-\mathrm{MnCl}_{2}$ and the substrate, $4.4 \mathrm{~mm}$-DL-isocitrate. A $25 \mu \mathrm{l}$ portion of the $50000 \mathrm{~g}$ supernatant fraction was pre-incubated for $15 \mathrm{~min}$ in the presence of the first three ingredients. The reaction was initiated by adding DL-isocitrate and following the rate of reduction of NADP at $340 \mathrm{~nm}$ at $25^{\circ}$. The reaction proceeded linearly for at least $60 \mathrm{~min}$ providing that the reaction contained less than $50 \mu \mathrm{g}$ supernatant-fraction protein.

GOT activity was determined by a modification of the method of Martin \& Herbein (1976). The reaction contained $50 \mathrm{~mm}$-HEPES, $200 \mathrm{~mm}$-L-aspartate, $0 \cdot 2 \mathrm{~mm}$-NADH, 1000 units malic dehydrogenase $(E C 1.1 .1 .37) / 1$ and the substrate, $15 \mathrm{~mm}$-2-oxoglutarate. A $25 \mu 1$ portion of the $50000 \mathrm{~g}$ supernatant fraction was pre-incubated for $15 \mathrm{~min}$ in the presence of the first four ingredients. The reaction was initiated by adding 2-oxoglutarate and following the rate of oxidation of NADH at $340 \mathrm{~nm}$ at $25^{\circ}$. The reaction proceeded linearly for at least $30 \mathrm{~min}$ providing that the reaction contained less than $50 \mu \mathrm{g}$ supernatant-fraction protein.

\section{Hormone and metabolite assays}

Both $T_{3}$ and $T_{4}$ concentrations were estimated with commercial, solid-phase kits (Immuchem Corp, Carson, CA). These assays were validated for avian samples by dispersing standards in charcoal-stripped chicken serum and by noting recovery of added $\mathrm{T}_{3}$ and $\mathrm{T}_{4}(98 \%)$. All hormone assays were conducted as single batches to eliminate interassay variation. The intra-assay coefficients of variation averaged 1.6 and $1.8 \%$ for $T_{3}$ and $\mathrm{T}_{4}$ respectively.

Plasma GH was estimated with a homologous chicken $\mathrm{GH}$ radioimmunoassay that has been extensively described (Vasilatos-Younken, 1986). Plasma IGF-1 was estimated with a heterologous radioimmunoassay as previously described (Dawe et al. 1988). ${ }^{125}$-labelled IGF-1 was purchased from Amersham Corp and purified human sequence IGF-1 for standard was supplied by Bachem, Torrance, CA. Primary antisera (rabbit anti-human IGF-1 was kindly provided by Dr Geoff Francis, CSIRO, Adelaide, Australia. Plasma glucose, triacylglycerols (Sigma Chemical Co., St Louis, MO) and non-esterified free fatty acids (NEFA; NEFA-C, Wako Chemical Co., Dallas) were determined with commercially available kits.

\section{Statistical analyses}

All data, except for those for in vitro lipogenesis, were analysed according to the model: $\mathrm{Y}=$ hormone (control or $\mathrm{T}_{3}$ ), diet (level of crude protein) and hormone $\times$ diet. The actual values for the energy: protein $(106,71,53$ and 43$)$ were used as the independent variables. In addition, the energy: protein value was split into linear and quadratic components for tests of statistical significance. All interactions involving the blocking factor were pooled with the residual. The condensed analyses of variance tables presented with the data only describe significance of pooled linear and quadratic effects. Data for enzyme activities were subjected to natural log transformations to decrease the mean square residual in the analysis of variance. This transformation was tried with all other data, but did not alter $F$ ratios. Data for in vitro lipogenesis were analysed as a split design with two error strata. The main treatment effects of diet and $T_{3}$ were tested against the between-plot error term, 
Table 2. The effects of dietary energy:protein value and triiodothyronine $\left(T_{3}\right)$ on chicken growth*

(Mean values for eight pen means (six chickens per pen) per dietary treatment)

\begin{tabular}{|c|c|c|c|c|c|c|c|c|}
\hline \multirow[t]{2}{*}{ Dietary energy : protein ( $\mathrm{MJ} / \mathrm{kg}$ protein) ... } & \multicolumn{2}{|c|}{106} & \multicolumn{2}{|c|}{71} & \multicolumn{2}{|c|}{53} & \multicolumn{2}{|c|}{43} \\
\hline & Mean & $\mathrm{SE}$ & Mean & SE & Mean & SE & Mean & SE \\
\hline \multicolumn{9}{|l|}{$28 \mathrm{~d}$ body weight $(\mathrm{g})$} \\
\hline Control & 453 & $17 \cdot 2$ & 953 & 26.7 & 992 & 13.9 & 871 & $20 \cdot 3$ \\
\hline$+1 \mathrm{mg} \mathrm{T}_{3} / \mathrm{kg} \operatorname{diet}$ & 304 & $11 \cdot 0$ & 807 & $14 \cdot 0$ & 796 & $35 \cdot 0$ & 650 & $14 \cdot 0$ \\
\hline \multicolumn{9}{|l|}{ Food efficiency (food intake/wt gain) } \\
\hline Control & $2 \cdot 34$ & $0 \cdot 23$ & $1 \cdot 72$ & 0.06 & 1.67 & 0.03 & $1 \cdot 75$ & 0.07 \\
\hline$+1 \mathrm{mg} \mathrm{T}_{3} / \mathrm{kg} \operatorname{diet}$ & $4 \cdot 35$ & $0 \cdot 25$ & 1.69 & 0.05 & $1 \cdot 83$ & 0.08 & $2 \cdot 35$ & $0 \cdot 11$ \\
\hline \multicolumn{9}{|l|}{ Food intake $7-28 \mathrm{~d}(\mathrm{~g})$} \\
\hline Control & 750 & $69 \cdot 1$ & 1404 & $14 \cdot 0$ & 1443 & $27 \cdot 1$ & 1297 & $65 \cdot 0$ \\
\hline$+1 \mathrm{mg} \mathrm{T}_{3} / \mathrm{kg} \operatorname{diet}$ & 748 & $32 \cdot 2$ & 1145 & 36.9 & 1203 & $46 \cdot 0$ & 1298 & $49 \cdot 0$ \\
\hline Diet variables & \multicolumn{2}{|c|}{$28 \mathrm{~d}$ body-wt } & \multicolumn{2}{|c|}{ Food efficiency } & \multicolumn{2}{|c|}{ Food intake } & & \\
\hline Energy:protein $(\mathrm{E}: \mathrm{P})$ & \multicolumn{2}{|c|}{$P<0.01$} & \multicolumn{2}{|c|}{$P<0.01$} & \multicolumn{2}{|c|}{$P<0.01$} & & \\
\hline $\operatorname{Dietary~}_{3}(\mathrm{~T})$ & \multicolumn{2}{|c|}{$P<0.01$} & \multicolumn{2}{|c|}{$P<0.01$} & \multicolumn{2}{|c|}{$P<0.01$} & & \\
\hline $\mathrm{E}: \mathrm{P} \times \mathrm{T}$ & \multicolumn{2}{|c|}{$P=0.23$} & \multicolumn{2}{|c|}{$P<0 \cdot 01$} & \multicolumn{2}{|c|}{$P=0.02$} & & \\
\hline
\end{tabular}

* For details of diets, see Table 1 and p. 668.

while ouabain and its associated interactions were tested against the within-plot error term. The general linear models procedure (GLM) was used for the analyses of transformed data, least squares means, and mean square components (Remington \& Schork, 1972).

\section{RESULTS}

\section{Growth and feed efficiency}

There were significant differences $(P<0.01)$ among treatment means for $28 \mathrm{~d}$ body-weights that could be attributed both to the energy: protein values of the diets as well to dietary $\mathrm{T}_{3}$ (Table 2). In addition, the main treatment effect of the energy:protein value (an increase in body-weight with a decrease in the ratio from 106 to $53 \mathrm{MJ} / \mathrm{kg}$ protein) could be further delineated into both significant linear and quadratic components. There were significant $(P<0.01)$ linear and quadratic effects of the energy: protein value on feed efficiency (an improvement in efficiency as the ratio decreased from 106 to $53 \mathrm{MJ} / \mathrm{kg}$ protein) as well as an apparent significant $(P<0.01) \mathrm{T}_{3} \times$ energy: protein interaction. A further examination of data revealed that this finding of significance could be attributed to simple effects of $\mathrm{T}_{3}$ when fed in conjunction with either the large $(106 \mathrm{MJ} / \mathrm{kg}$ protein) or the small $(43 \mathrm{MJ} / \mathrm{kg}$ protein) energy:protein diets. There were also significant $(P<0.01)$ linear and quadratic effects of the energy:protein value on food intake efficiency (a decrease in intake as the value decreased from 106 to $53 \mathrm{MJ} / \mathrm{kg}$ protein. In contrast to effects on body-weight, $\mathrm{T}_{3}$ had no effect on food intake.

\section{Plasma metabolites}

Neither energy: protein value nor dietary $T_{3}$ changed plasma glucose concentrations (Table $3)$. Plasma-free fatty acids were also unaffected by the energy:protein value of the diets; however, there was a significant $(P<0.01)$ effect of dietary $\mathrm{T}_{3}$ when data were pooled across the four energy:protein values. The overall mean for dietary $T_{3}$ was $225 \mu \mathrm{mol} / 1$ compared with $144 \mu \mathrm{mol} / 1$ for the unsupplemented groups. In particular, the addition of 
Table 3. The effects of dietary energy:protein and triiodothyronine $\left(T_{3}\right)$ on plasma metabolites in chickens*

(Mean values for eight pen means (two observations per pen) per dietary treatment)

\begin{tabular}{|c|c|c|c|c|c|c|c|c|}
\hline \multirow[t]{2}{*}{ Dietary energy : protein ( $\mathrm{MJ} / \mathrm{kg}$ protein) ... } & \multicolumn{2}{|c|}{106} & \multicolumn{2}{|c|}{71} & \multicolumn{2}{|c|}{53} & \multicolumn{2}{|c|}{43} \\
\hline & Mean & $\mathrm{SE}$ & Mean & $\mathrm{SE}$ & Mean & SE & Mean & se \\
\hline \multicolumn{9}{|l|}{ Plasma glucose, $\mathrm{mg} / 100 \mathrm{ml}$} \\
\hline Control & 216 & $9 \cdot 0$ & 225 & $4 \cdot 7$ & 228 & $6 \cdot 4$ & 223 & 4.7 \\
\hline$+1 \mathrm{mg} \mathbf{T}_{3} / \mathrm{kg}$ diet & 227 & $6 \cdot 6$ & 200 & 5.9 & 232 & $5 \cdot 9$ & 211 & $10 \cdot 3$ \\
\hline \multicolumn{9}{|l|}{ Free fatty acids $(\mu \mathrm{mol} / 1)$} \\
\hline Control & 127 & $13 \cdot 4$ & 151 & $15 \cdot 2$ & 141 & $10 \cdot 7$ & 156 & $19 \cdot 1$ \\
\hline$+1 \mathrm{mg} \mathrm{T}_{3} / \mathrm{kg}$ diet & 175 & $26 \cdot 1$ & 297 & $41 \cdot 6$ & 223 & 33.9 & 205 & $42 \cdot 9$ \\
\hline \multicolumn{9}{|l|}{ Triacylglycerols (mg/l) } \\
\hline Control & 1310 & 110 & 1080 & 118 & 980 & 64 & 860 & 101 \\
\hline$+1 \mathrm{mg} \mathrm{T}_{3} / \mathrm{kg}$ diet & 1680 & 124 & 1350 & 99 & 1250 & 144 & 1330 & 84 \\
\hline \multicolumn{9}{|l|}{ Uric acid (mg/l) } \\
\hline Control & 27 & 4 & 41 & 4 & 50 & 7 & 92 & 14 \\
\hline$+1 \mathrm{mg} \mathrm{T}_{3} / \mathrm{kg}$ diet & 21 & 3 & 30 & 2 & 35 & 3 & 74 & 17 \\
\hline Diet variables & \multicolumn{2}{|c|}{ Glucose } & \multicolumn{2}{|c|}{$\begin{array}{c}\text { Free fatty } \\
\text { acids }\end{array}$} & \multicolumn{2}{|c|}{ Triacylglycerols } & \multicolumn{2}{|c|}{ Uric acid } \\
\hline Energy: protein $(E: P)$ & \multirow{3}{*}{\multicolumn{2}{|c|}{$\begin{array}{l}P=0.11 \\
P=0.29 \\
P=0.08\end{array}$}} & \multicolumn{2}{|c|}{$P=0.12$} & \multicolumn{2}{|c|}{$P<0.01$} & \multicolumn{2}{|c|}{$P<0.01$} \\
\hline Dietary $\mathrm{T}_{3}(\mathrm{~T})$ & & & \multirow{2}{*}{\multicolumn{2}{|c|}{$\begin{array}{l}P<0.01 \\
P=0.32\end{array}$}} & \multicolumn{2}{|c|}{$P<0.01$} & \multirow{2}{*}{\multicolumn{2}{|c|}{$P=0.01$}} \\
\hline $\mathrm{E}: \mathrm{P} \times \mathrm{T}$ & & & & & $P=$ & 79 & & \\
\hline
\end{tabular}

* For details of diets, see Table 1 and p. 668.

$\mathrm{T}_{3}$ increased NEFA in that group of chickens fed on the diet containing $71 \mathrm{MJ} / \mathrm{kg}$ protein. A decrease in the energy:protein value decreased $(P<0.01)$ plasma triacylglycerols. In contrast, the overall mean triacylglycerol concentration for those chickens fed on $T_{3}$ was significantly greater than the pooled value for chickens fed on the respective control levels of crude protein $(1400 \mathrm{v} .1060 \mathrm{mg} / \mathrm{l})$. Decreasing the energy: protein value increased $(P<$ $0.01)$ plasma uric acid concentrations. In contrast, pooling data for $\mathrm{T}_{3}$ treatments across protein levels revealed a significant $(P=0.01)$ decrease due to the inclusion of $\mathrm{T}_{3}$ in the diets $(41.7$ v. $52.5 \mathrm{mg} / 1)$.

\section{Plasma hormones}

Plasma $\mathrm{T}_{3}$ was slightly influenced $(P<0.05)$ by dietary energy: protein and was markedly increased $(P<0.01)$ by dietary $\mathrm{T}_{3}$ (Table 4$)$. Overall mean plasma $\mathrm{T}_{3}$ was significantly greater for chickens fed on $\mathrm{T}_{3}(5.9 \vee 2.4 \mathrm{ng} / \mathrm{ml})$. The apparent significant $(P<0.01)$ effect of the energy:protein value on plasma $\mathrm{T}_{4}$ could be traced to a significant $(P<0.01)$ energy:protein $\times \mathrm{T}_{3}$ interaction. On further examination of possible causes of this interaction, it was shown that plasma $T_{4}$ concentrations in groups fed on $T_{3}$ were similar across all protein levels, contrasting with differences in $T_{4}$ among the unsupplemented groups. The overall mean for plasma $T_{4}$ was less for chickens fed on $T_{3}(2.2 v 10.8 \mathrm{ng} / \mathrm{ml})$.

There was an inverse, significant $(P<0.01)$ effect of the energy: protein value on plasma IGF-1 where decreasing the value from 106 to $71 \mathrm{MJ} / \mathrm{kg}$ protein increased plasma IGF-1. There was no effect of dietary $T_{3}$ on plasma IGF-1. Plasma GH declined as the energy: protein value decreased from 106 to $71 \mathrm{MJ} / \mathrm{kg}$ protein, remained unchanged as the value further decreased from 71 to $53 \mathrm{MJ} / \mathrm{kg}$ protein and increased as the value finally decreased from 53 to $43 \mathrm{MJ} / \mathrm{kg}$ protein. This pattern of change was noted whether or not $\mathrm{T}_{3}$ was provided in the diets. It should be noted that dietary $\mathrm{T}_{3}$ did result in an overall decrease $(P<0.01)$ in plasma GH $(11.6 v .43 .5 \mathrm{ng} / \mathrm{ml})$. 
Table 4. The effects of dietary energy: protein and triiodothyronine $\left(T_{3}\right)$ on plasma hormone concentrations in chickens*

(Mean values for eight pen means (two observations per pen) per dietary treatment)

\begin{tabular}{|c|c|c|c|c|c|c|c|c|}
\hline \multirow[t]{2}{*}{ Dietary energy: protein (MJ/kg protein) ... } & \multicolumn{2}{|c|}{106} & \multicolumn{2}{|c|}{71} & \multicolumn{2}{|c|}{53} & \multicolumn{2}{|c|}{43} \\
\hline & Mean & SE & Mean & SE & Mean & SE & Mean & SE \\
\hline \multicolumn{9}{|l|}{$\mathrm{T}_{3}(\mathrm{ng} / \mathrm{ml})$} \\
\hline Control & $2 \cdot 4$ & $0 \cdot 3$ & $2 \cdot 8$ & $0 \cdot 2$ & $2 \cdot 3$ & $0 \cdot 1$ & $2 \cdot 1$ & $0 \cdot 2$ \\
\hline$+1 \mathrm{mg} \mathrm{T}_{3} / \mathrm{kg}$ diet & $8 \cdot 2$ & $1 \cdot 0$ & $4 \cdot 8$ & $0 \cdot 9$ & $6 \cdot 7$ & $1 \cdot 3$ & 42 & 0.6 \\
\hline \multicolumn{9}{|l|}{$\mathrm{T}_{4}(\mathrm{ng} / \mathrm{ml})$} \\
\hline Control & $5 \cdot 1$ & 0.5 & $10 \cdot 9$ & $0 \cdot 9$ & $15 \cdot 3$ & $1 \cdot 4$ & $11 \cdot 7$ & 0.9 \\
\hline$+1 \mathrm{mg} \mathrm{T}_{3} / \mathrm{kg}$ diet & $1 \cdot 8$ & $0 \cdot 1$ & $2 \cdot 1$ & $0 \cdot 1$ & $2 \cdot 7$ & $0 \cdot 2$ & $2 \cdot 4$ & $0 \cdot 2$ \\
\hline \multicolumn{9}{|l|}{$\mathrm{IGF}-\mathrm{l}(\mathrm{ng} / \mathrm{ml})$} \\
\hline Control & $12 \cdot 5$ & 0.5 & $18 \cdot 8$ & 0.6 & $19 \cdot 3$ & 0.5 & $17 \cdot 3$ & $0 \cdot 6$ \\
\hline$+1 \mathrm{mg} \mathbf{T}_{3} / \mathrm{kg}$ diet & $12 \cdot 5$ & 0.9 & $18 \cdot 3$ & $1 \cdot 7$ & $17 \cdot 3$ & 0.5 & $16 \cdot 3$ & $1 \cdot 4$ \\
\hline \multicolumn{9}{|l|}{$\mathrm{GH}(\mathrm{ng} / \mathrm{ml})$} \\
\hline Control & $78 \cdot 1$ & $11 \cdot 2$ & $20 \cdot 8$ & $4 \cdot 1$ & $24 \cdot 8$ & $6 \cdot 6$ & $50 \cdot 3$ & 8.9 \\
\hline$+1 \mathrm{mg} \mathrm{T} / \mathrm{kg}$ diet & $22 \cdot 3$ & $2 \cdot 3$ & $6 \cdot 2$ & $0 \cdot 9$ & $7 \cdot 1$ & $1 \cdot 2$ & $10 \cdot 7$ & $1 \cdot 2$ \\
\hline Diet variables & \multirow{2}{*}{\multicolumn{2}{|c|}{$\begin{array}{c}\mathrm{T}_{3} \\
p=0.05\end{array}$}} & \multicolumn{2}{|c|}{$\mathrm{T}_{4}$} & \multicolumn{2}{|c|}{ [GF-] } & \multicolumn{2}{|c|}{ GH } \\
\hline Energy:protein $(E: P)$ & & & \multicolumn{2}{|c|}{$P<0.01$} & \multicolumn{2}{|c|}{$P<0.01$} & \multicolumn{2}{|c|}{$P<0.01$} \\
\hline Dietary $T_{3}(T)$ & \multicolumn{2}{|c|}{$P<0.01$} & \multirow{2}{*}{\multicolumn{2}{|c|}{$\begin{array}{l}P<0.01 \\
P<0.01\end{array}$}} & \multirow{2}{*}{\multicolumn{2}{|c|}{$\begin{array}{l}P=0.21 \\
P=0.78\end{array}$}} & \multirow{2}{*}{\multicolumn{2}{|c|}{$\begin{array}{l}P<0.01 \\
P=0.01\end{array}$}} \\
\hline $\mathrm{E}: \mathrm{P} \times \mathrm{T}$ & \multicolumn{2}{|c|}{$P=0.05$} & & & & & & \\
\hline
\end{tabular}

$\mathrm{T}_{3}$, triiodothyronine; $\mathrm{T}_{4}$, thyroxine; IGF-1, insulin-like growth factor $1 ; \mathrm{GH}$, growth hormone.

* For details of diets, see Table 1 and p. 668 .

Table 5. The effects of dietary energy:protein, triiodothyronine $\left(T_{3}\right)$ and ouabain on in vitro hepatic lipogenesis in chickens ${ }^{*} \dagger$

(Mean values for eight pen means (two observations per pen) per dietary treatment are expressed as nmol substrate incorporated per $100 \mathrm{mg}$ liver)

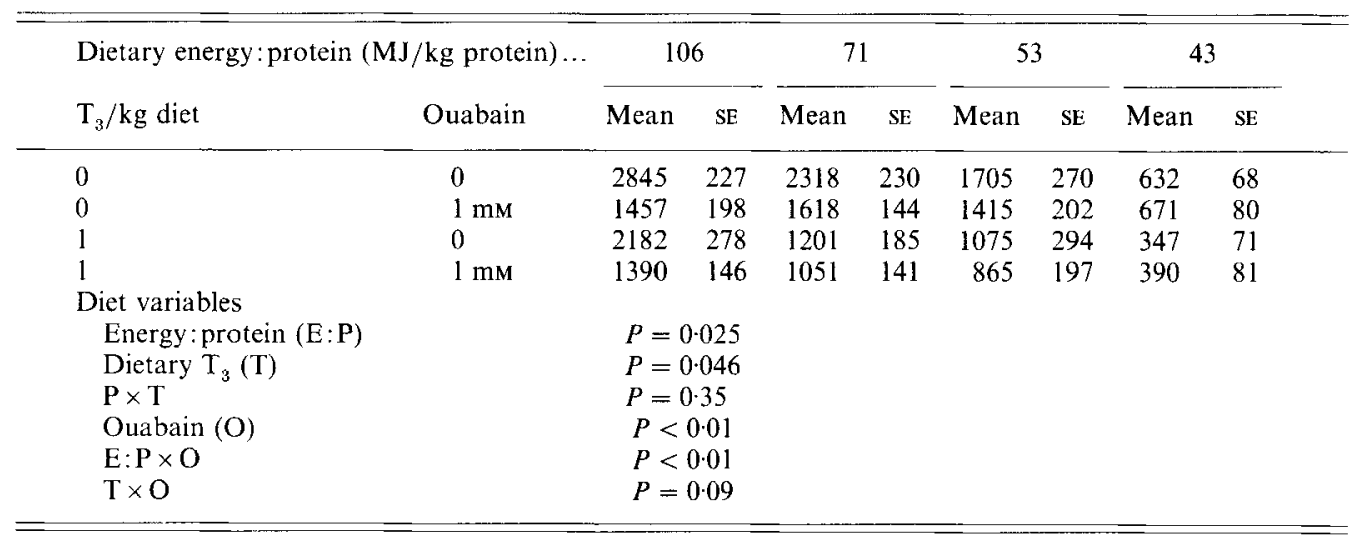

* For details of diets, see Table 1 and p. 668.

†For details of procedures, see pp. 668-670.

The effects of the energy: protein value and dietary $T_{3}$ as well as in vitro ouabain are presented in Table 5 . There was an overall decrease in lipogenesis corresponding to a decrease in the energy: protein value $(P=0.01)$. Pooling data across crude protein levels showed that dietary $\mathrm{T}_{3}$ decreased lipogenesis by $30 \%(10440 \mathrm{v} .15780 \mathrm{ng} / \mathrm{g}$ liver $; P<0 \cdot 01)$. 
Table 6. The effects of dietary energy:protein and triiodothyronine $\left(T_{3}\right)$ on hepatic enzyme activities in chickens (one unit is that amount of enzyme resulting in the production of 1 umol oxidized or reduced $N A D(P) / \min$ at $\left.25^{\circ}\right)^{* \dagger}$

(Mean values for eight pen means (two observations per pen) per dietary treatment are expressed as units $/ \mathrm{kg}$ body weight)

\begin{tabular}{|c|c|c|c|c|c|c|c|c|}
\hline \multirow[t]{2}{*}{ Dietary energy: protein ( $\mathrm{MJ} / \mathrm{kg}$ protein) ... } & \multicolumn{2}{|c|}{106} & \multicolumn{2}{|c|}{71} & \multicolumn{2}{|c|}{53} & \multicolumn{2}{|c|}{43} \\
\hline & Mean & $\mathrm{SE}$ & Mean & $\mathrm{SE}$ & Mean & SE & Mean & $\mathrm{SE}$ \\
\hline \multicolumn{9}{|l|}{ GOT: } \\
\hline Control & 774 & 84 & 1062 & 70 & 1446 & $13 \cdot 1$ & 2586 & 547 \\
\hline \multirow{2}{*}{\multicolumn{9}{|c|}{ ICD (NADP): }} \\
\hline & & & & & & & & \\
\hline$+1 \mathrm{mg} \mathrm{T}_{3} / \mathrm{kg}$ diet & 173 & $\begin{array}{l}35 \\
22\end{array}$ & $\begin{array}{l}349 \\
384\end{array}$ & $\begin{array}{l}33 \\
50\end{array}$ & $\begin{array}{l}563 \\
631\end{array}$ & $\begin{array}{l}3 \cdot 3 \\
9 \cdot 9\end{array}$ & $\begin{array}{l}858 \\
849\end{array}$ & 136 \\
\hline \multicolumn{9}{|l|}{ ME: } \\
\hline Control & 159 & 22 & 180 & 24 & 109 & 18 & 35 & 8 \\
\hline$+1 \mathrm{mg} T_{3} / \mathrm{kg}$ diet & 141 & 20 & 121 & 10 & 75 & 18 & 32 & 9 \\
\hline Diet variables & \multicolumn{2}{|c|}{ GOT } & \multicolumn{2}{|c|}{ NADP $(I C D)$} & \multicolumn{2}{|c|}{$\mathrm{ME}$} & & \\
\hline Energy:protein (E:P) & \multicolumn{2}{|c|}{$P<0.0 \mathrm{l}$} & \multicolumn{2}{|c|}{$P<0.01$} & \multicolumn{2}{|c|}{$P<0.01$} & & \\
\hline Dietary $T_{3}(T)$ & \multirow{2}{*}{\multicolumn{2}{|c|}{$\begin{array}{l}P=0.75 \\
P=0.93\end{array}$}} & \multirow{2}{*}{\multicolumn{2}{|c|}{$P=0.84$}} & \multirow{2}{*}{\multicolumn{2}{|c|}{$P=0.03$}} & & \\
\hline$E: P \times T$ & & & & & & & & \\
\hline
\end{tabular}

* For details of diets, see Table 1 and p. 668.

† GOT, glutamic-oxaloacetic aminotransferase (EC 2.6.1.1); ICD (NADP), isocitrate dehydrogenase (NADP) (EC 1.1.1.42); ME, malic enzyme (EC 1.1.1.40.).

A similar effect for in vitro ouabain was also noted $(11010 v .15210 \mathrm{ng} / \mathrm{g}$ liver $; P<0.01)$. A significant ouabain $\times \mathrm{T}_{3}$ interaction was not observed. A significant $(P<0.01)$ energy: protein $\times$ ouabain interaction may imply that effects of ouabain in vitro are specific to the high rates of lipogenesis that accompany the feeding of diet containing the largest energy: protein value ( $106 \mathrm{MJ} / \mathrm{kg}$ of protein).

The effects of the energy: protein value and dietary $T_{3}$ on the activities of certain hepatic enzymes are presented in Table 6 . Both GOT and ICD activities increased significantly $(P<0.01)$ with a decrease in the energy : protein value. In contrast, dietary $\mathrm{T}_{3}$ did not change enzyme activities. Significant diet $\times \mathrm{T}_{3}$ interactions were not observed for the activities of either of these enzymes. In contrast, ME activity decreased significantly $(P<0.01)$ with an increase in the energy: protein value. Dietary $\mathrm{T}_{3}$ did result in an overall significant decrease $(P<0.05)$ in ME activity $(92 v .120 .7$ units $/ \mathrm{kg}$ body-weight $)$.

\section{DISCUSSION}

The objectives of the present study were to determine the effects of dietary energy: protein values and $T_{3}$ on in vitro lipid metabolism, growth and metabolic hormone concentrations. Plasma GH measurements are necessary because the efficacy of dietary thyroid hormone treatments can be verified by monitoring changes in plasma GH (Harvey, 1983; Cogburn et al. 1989). Plasma IGF-1 was measured to determine if the putative GH-IGF-1 axis was altered by feeding either a thyroid hormone or diets containing different energy: protein values. Although, depressed IGF-1 values in humans can be returned to normal with $T_{4}$ replacement, it was somewhat surprising that dietary $T_{3}$ lacked effect on plasma IGF-1 concentrations in the present study. 
The findings in the present study also point out the caution that must be used in analysing effects of dietary crude protein on metabolism. Specifically, responses may not always follow linear trends as crude protein increases. For example, if dietary crude protein levels in experimental diets are kept between 180 and $230 \mathrm{~g} / \mathrm{kg}$ diet $(71$ and $53 \mathrm{MJ} / \mathrm{kg}$ protein respectively) to approach typical broiler production diets, there will be few differences in the concentrations of the plasma hormones implicated in growth regulation. Likewise, dietary thyroid hormones may not alter growth or food utilization if this optimal dietary energy range is utilized. A further implication is that neither GH nor IGF-1 reflect either growth or protein nutrition. Our findings show that, when wide fluctuations are made in the dietary energy: crude protein level, metabolic hormone concentrations can reflect changes in growth. This theory is especially noticeable after examining changes in growth and hormone concentrations as the dietary crude protein was increased from 120 to $180 \mathrm{~g} / \mathrm{kg}$ diet (energy: protein decreased from $106 \mathrm{MJ} / \mathrm{kg}$ protein to $71 \mathrm{MJ} / \mathrm{kg}$ protein).

There are many reports concerning the relationship between dietary energy and protein and subsequent effects on intermediary metabolism; few studies attempt to explain the basis of changes in the lean:fat ratio in the animal carcass and the energy:protein relationship in the diet. Yeh \& Leveille (1969) found an inverse relationship between the level of the dietary protein and the subsequent rate of in vitro lipogenesis, and speculated that an increase in the dietary protein level decreased the flow of substrates through glycolysis and increased the production of glucose from substrates that were formerly in the pathways leading to fat synthesis. The enzyme activities in the present study also suggest that ICD may function in both lipid and protein metabolism by providing a residual capacity for the production of reducing equivalents during a period of decreased $\mathrm{ME}$ activity. Intracellular competition may exist between acetyl-CoA carboxylase $(E C$ 6.4 .1 .2) and the aconitase (EC 4.2.1.3)-ICD pathway for limited cytoplasmic citrate. Thus, the requirement for 2-oxoglutarate (a product of the reaction catalysed by $I C D$ ) as a reactant for transamination occurring during increased dietary protein intakes, would depress citrate levels to a point that activation of acetyl-CoA carboxylase would not occur.

Weaving together the three elements in the present study (dietary energy : protein, dietary $\mathrm{T}_{3}$ and in vitro inhibition of $\mathrm{Na}^{+}, \mathrm{K}^{+}$-transporting ATPase activity) did not produce a satisfactory explanation of a diet $x$ thyroid axis that involved an increase in $\mathrm{T}_{3}$-dependent lipogenesis. It was subsequently determined that both dietary $T_{3}$ and in vitro ouabain decreased lipogenesis to an equal degree. It was originally proposed that feeding $T_{3}$ would increase that proportion of lipogenesis sensitive to inhibition of $\mathrm{Na}^{+}-\mathrm{K}^{+}$transport. It was reasonable to assume that transport systems also exist for lipogenic substrates and that these systems also require significant $\mathrm{O}_{2}$ consumption to support $\mathrm{Na}^{+}, \mathrm{K}^{+}$-transporting ATPase activity. A recent series of reports (Spratt et al. $1990 a, b$ ) examined tissue respiration rates in poultry and found that ouabain-sensitive respiration was much lower in poultry than in other livestock species.

Both in vitro ouabain and dietary $T_{3}$ constrain lipogenesis in chickens fed on a diet containing $106 \mathrm{MJ} / \mathrm{kg}$ crude protein. It is unknown at the present time if these effects are specific to lipogenesis in general or to the feeding of a diet containing a large energy : protein value. Moreover, it could not be shown that dietary $T_{3}$ treatments altered the portion of de novo lipogenesis susceptible to inhibition by ouabain. Thus, it can be implied that the role of dietary $\mathrm{T}_{3}$ in the regulation of lipid metabolism in broilers does not involve changes in $\mathrm{Na}^{+}, \mathrm{K}^{+}$-transporting ATPase.

\section{REFERENCES}

Adeola, A., Young, L. G., McBride, B. W. \& Ball, R. O. (1989). In vitro $\mathrm{Na}^{+}$, K+-ATPase (EC 3.6.1.3)dependent respiration and protein synthesis in skeletal muscle of pigs fed at three dietary protein levels. British Joumal of Nutrition 61, 453-465. 
Berdanier, C. D. \& Shubeck, D. (1981). Effects of thyroid hormones on mitochondrial activity in lipemic BHE rats. Proceedings of the Society for Experimental Biology and Medicine 166, 348-354.

Cleland, W. W., Thompson, V. M. \& Barden, R. E. (1969). Isocitrate dehydrogenase (TPN specific) from pig heart. In Methods in Enzymology, vol. 13, pp. 30-33 [J. M. Lowenstein, editor]. New York: Academic Press.

Cogburn, L. A., Liou, S. S., Alfonso, C. P., McGuiness, M. C. \& McMurtry, J. P. (1989). Dietary thyrotropinreleasing hormone stimulates growth rate and increases the insulin:glucagon molar ratio of broiler chickens. Proceedings of the Society for Experimental Biology and Medicine 192, 127-134.

Dawe, S. R., Francis, G. L., McNamara, P. J., Wallace, J. C. \& Ballard, P. J. (1988). Purification, partial sequences and properties of chicken insulin-like growth factors. Journal of Endocrinology 117, 173-181.

Donaldson, W. E. (1985). Lipogenesis and body fat in chicks: effects of calorie:protein ratios and dietary fat. Poultry Science 64, 1199-1204.

Donaldson, W. E., Combs, G. F. \& Romoser, G. L. (1956). Studies on energy levels in poultry rations. 1. The effect of calorie-protein of the ration on growth, nutrient utilization and body composition of chicks. Poultry Science 35, 1100-1204.

Folch, J., Lees, M. \& Sloane-Stanley, G. H. (1957). A simple method for the isolation and purification of total lipids from animal tissues. Joumal of Biological Chemistry 226, 497-500.

Glynn, I. M. (1964). The action of cardiac glycosides on ion movements. Pharmacological Reviews 16, 381-408.

Hanks, J. H. \& Wallace, R. E. (1949). Relation of oxygen and temperature in the preservation of tissues by refrigeration. Proceedings of the Society for Experimental Biology and Medicine 71, 196-200.

Harvey, S. (1983). Thyroid hormones inhibit growth hormone secretion in domestic fowl (Gallus domesticus). Jotunal of Endocrinology 98, 129-135.

Hiligartner, F. B.\& Romsos, D. R. (1985). Regulation of iodothyronine 5'-deiodination in lean and obese (ob/ob) mice. American Journal of Physiology 249, E209-E218.

Hsu, R. Y. \& Lardy, H. A. (1969). Malic enzyme. In Methods in Enzymology, vol. 13, pp. $230-235$ [J. M. Lowenstein, editor]. New York: Academic Press.

Ismail-Beigi, F. \& Edelman, I. S. (1970). Mechanism of thyroid calorigenesis: role of active sodium transport. Proceedings of the National Academy of Sciences, USA 67, 1071-1078.

Kim, M.-J. \& Berdanier, C. D. (1989). Influence of menhaden oil on mitochondrial respiration in BHE rats. Proceedings of the Society for Experimental Biology and Medicine 192, 172-176.

Martin, R. J. \& Herbein, J. H. (1976). A comparison of the enzyme levels and in vitro utilization of various substrates for lipogenesis in pair-fed lean and obese pigs. Proceedings of the Society for Experimental Biology and Medicine 151, 231-235.

Milligan, L. P. \& McBride, B. W. (1985). Energy costs of ion pumping by animal tissues. Journal of Nutrition 114, $1374-1382$.

Remington, R. D. \& Schork, M. A. (1972). Statistics with Applications to the Biological and Health Sciences. Englewood Cliffs, New Jersey: Prentice-Hall.

Rosebrough, R. W. \& Steele, N. C. (1985). Energy and protein relations in the broiler. 1. Effect of protein levels and feeding regimes on growth, body composition and in vitro lipogenesis in broiler chickens. Poultry Science 64, $119-126$.

Rosebrough, R. W. \& Steele, N. C. (1987). Methods to assess glucose and lipid metabolism in avian liver explants. Comparative Biochemistry and Physiology 88A, 1041-1049.

Sigma Bulletin 16 UV (1986). Glucose. St. Louis, MO: Sigma Diagnostics.

Sigma Bulletin 335 UV (1988). Triglyceride $(U V)$. St Louis, MO: Sigma Diagnostics.

Spratt, R. S., Bayley, H. S., McBride, B. W. \& Leeson, S. (1990a). Energy metabolism of broiler breeder hens. 1. The partition of dietary energy intake. Poultry Science 69, 1339-1347.

Spratt, R. S., Bayley, H. S., McBride, B. W. \& Leeson, S. (1990b). Energy metabolism of broiler breeder hens. 2. Contribution of tissues to total heat production in fed and fasted hens. Poultry Science 69, 1348-1356.

Thomas, O. P. \& Combs, G. F. (1967). Relationship between serum protein level and body composition in the chick. Journal of Nutrition 91, 468-472.

Vasilatos-Younken, R. (1986). Preparation and culture of dispersed avian pituitary cells, and age-related changes in pituitary weight and growth hormone content. General and Comparative Endocrinology 64, 99-106.

Wako Bulletin (1986). NEFA-C. Dallas, TX: Wako Chemicals.

Yeh, Y. Y. \& Leveille, G. A. (1969). Effect of dietary protein on hepatic lipogenesis in the growing chick. Journal of Nutrition $98,356-366$.

York, D. A., Bray, G. A. \& Yukimura, Y. (1978). An enzymatic defect in the obese (ob/ob) mouse: loss of thyroid-induced sodium- and potassium-dependent adenosinetriphosphatase. Proceedings of the National Academy of Sciences, USA 75, 477-481. 